\title{
Documentary analysis in the study of architectural designs of a hospital in the city of São Paulo
}

\author{
A análise documental no estudo de projetos arquitetônicos de um hospital paulistano \\ El análisis documental en el estudio de proyectos arquitectónicos de un hospital de la ciudad de São Paulo
}

'Universidade Federal de São Paulo. São Paulo, São Paulo, Brazil.

How to cite this article:

Draganov PB, Sanna MC. Documentary analysis in the study of architectural designs of a hospital in the city of São Paulo. Rev Bras Enferm. 2020;73(3):e20180879. doi: http://dx.doi.org/10.1590/0034-7167-2018-0879

Corresponding author:

Patricia Bover Draganov

E-mail: patricia.draganov@anhembi.br

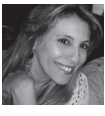

EDITOR IN CHIEF: Antonio José de Almeida Filho ASSOCIATE EDITOR: Rafael Silva

Submission: 02-03-2019

Approval: 05-24-2019

\begin{abstract}
Objectives: to report the experience of using architectural designs of a hospital for a historical documentary research. Methods: report of the experience of the methodological route of using architectural designs of a model hospital from 1974 to 2002. Results: after being spread on a worksheet, the projects of interest were selected, enabling the data arrangement, where the analytical chart was applied, containing: context; authorship; authenticity/ reliability; nature of the text and preliminary analysis. The findings were grouped by pertinence and similarity, resulting in the construction of categories of analysis. Final Considerations: architectural design is a challenging source, both for its pursuit, since it took two and a half years until it was legally licensed, as well as for involving specific terminologies and symbology of its own. A special attention should be given to the selection criteria, organization and analysis of the document, and sharing the access of unusual sources with the health area, like this one, so as to stimulate the development of research. Descriptors: Nursing History; Documents; Hospital Architecture; Evidence-Based Architectural Design; Historiography.
\end{abstract}

\section{RESUMO}

Objetivos: relatar a experiência do uso de projetos arquitetônicos de um hospital para uma pesquisa histórico-documental. Métodos: relato de experiência do percurso metodológico do uso de projetos arquitetônicos de 1974 a 2002 de um hospital modelar. Resultados: após planilhados, os projetos de interesse foram selecionados, criando um arranjo de dados em que foi aplicada a ficha analítica contendo: contexto; autoria; autenticidade/confiabilidade; natureza do texto e análise preliminar. Os achados foram agrupados por pertinência e similaridade, resultando na construção de categorias de análise. Considerações Finais: o projeto arquitetônico é uma fonte desafiadora, tanto em sua busca, visto que foram necessários dois anos e meio até que fossem licenciados legalmente, como por envolver terminologias específicas e simbologias próprias. Deve-se ter atenção aos critérios de seleção, à organização e à análise do documento, e compartilhar o manejo de fontes incomuns na área da saúde, como esta, a fim de favorecer o desenvolvimento da pesquisa.

Descritores: História da Enfermagem; Documentos; Arquitetura Hospitalar; Projeto Arquitetônico Baseado em Evidências; Historiografia.

\section{RESUMEN}

Objetivos: informar la experiencia del uso de proyectos arquitectónicos de un hospital, en una investigación histórica y documental. Métodos: reporte de experiencia del recorrido metodológico del uso de proyectos arquitectónicos de 1974 a 2002 de un hospital modelar. Resultados: después de insertar los proyectos en planillas, se seleccionaron los proyectos de interés, creando un arreglo de datos en que se aplicó la ficha analítica que contenía: contexto; autoría; autenticidad/fiabilidad; naturaleza del texto y análisis preliminar. Los hallazgos fueron agrupados por pertinencia y semejanza, resultando en la construcción de categorías de análisis. Consideraciones Finales: el proyecto arquitectónico es una fuente desafiante, tanto para su búsqueda, ya que fueron necesarios dos años y medio hasta que recibieron la licencia legal, como por involucrar terminologías específicas y simbologías propias. Se debe prestar atención a los criterios de selección, organización y análisis del documento y compartir el manejo de fuentes inusuales en el área de la salud, como ésta, a fin de favorecer el desarrollo de la investigación.

Descriptores: Historia de la Enfermería; Documentos; Arquitectura y Construcción de Hospitales; Diseño de Instalaciones Basado en Evidencias; Historiografía. 


\section{INTRODUCTION}

The aim of the historical research is to interpret the past and to subsidize the comprehension of the present. However, to make it possible, the documents used as sources must be well organized, interpreted and analyzed, according to the objectives of the investigation proposed. Therefore, the specific path of this research will have, as background, the methodological treatment of the documents pointed out.

The documentary analysis, one of the techniques employed in the historical investigation, goes through stages that have the purpose of studying and understanding documents, so as to relate them to social, political and economic circumstances involving a certain fact. The document is the result of an assembly, conscious or unconscious, of the societies that produced it and also of the successive periods during which they continued to live. Documents are vestiges of the past, which can be historically analyzed, and which, deciphered, can become a historical source. Documents should be considered living structures and networks of action when approached from their historical, social, political and economic contexts ${ }^{(1-2)}$.

Among the types of documents that lead to these interpretations, we highlight in this study the architectural projects of a reference hospital elaborated during the period from 1974 to $2002^{(3)}$, when transformations occurred in the norms for construction and remodeling of health care establishments (EAS), which were applied in the modification of the hospital building in focus.

The architectural design is defined as a research source capable of informing and putting into question disciplinary issues and others, related to society, economy, politics, types of real estate investment, culture and technique of a given period ${ }^{(1-2,4)}$.

The dialectical relationship between documents, such as architectural designs, and the historical matter may favor the construction of analyzes, as well as the interweaving between the history of architecture and the social, political, economic and cultural histories and the ones related to other areas of knowledge. Thus, analyzing architectural production under various prisms, one can construct a complex and powerful historical reading, and launch new hypotheses, illuminating old sources of research and contributing to other interpretations of a given time ${ }^{(4)}$.

Architecture as an activity is a multidisciplinary field that basically includes mathematics, natural sciences, arts, technology, social sciences, politics, history and philosophy, among others. Although it has its own and complex language, the EAS architecture had significant contributions from nurses ${ }^{(5)}$.

Nurse Florence Nightingale, in the book Notes on Hospitals, from her observations on the pavilion plan system, laid the foundations and dimensions of what later became known as the "Nightingale Ward." She used architectural designs of the time to compose guidelines for building and restoring nineteenthcentury English hospitals, and this work was essential to reduce considerably the morbidity and mortality rates of the time. Today some of her prescriptions are still considered essential for building and renovating $\mathrm{EAS}^{(5-7)}$.

The history of norms to build and renovate EAS in Brazil also had the relevant contribution of nurses, who participated actively in the transformations of these spaces. Moreover, the planning, programming, creating and evaluating EAS architectural designs are vital for the quality in health care assistance, since architecture, since the 18th century, is recognized as a therapeutic element ${ }^{(8)}$.

The management of architectural projects of EAS is included in the work process "Administration in Nursing - the management of physical resources". In this area, the competent and responsible role of the nurse requires technical and scientific knowledge, skills and attitudes in the areas of architecture, design, decoration, legislation and designation of the compartments, among others. Thus, the reading of architectural drawings is one of the skills nurses must develop in their professional practice ${ }^{(9)}$.

An article entitled "Hospital physical resources in Brazil: a bibliometric study", published in the Revista Brasileira de Biblioteconomia e Documentação (Brazilian Journal of Library and Information Science) in 2016, was developed to identify and describe the Brazilian scientific production in theses and dissertations, in the repositories of the Brazilian Federal Agency for Support and Evaluation of Graduate Education (CAPES) and the Brazilian Institute of Information in Science and Technology (IBICT), on physical resources in hospital environments. The article proves the vigorous intersection of the architecture with the health sciences and concludes that studies on this subject, developed by nurses, are scarce and that the use of architectural designs in research on the history of nursing were not found ${ }^{(10)}$.

Working with architectural designs is not an easy exercise, because it uses a specific language, belonging to a particular area - architecture. Disseminating the methodological framework of a study with this raw material seems quite suitable, as it may contribute to other research in this area and/or this type of material. In addition, the method elucidates the ability to observe, select and organize scientifically the paths that must be traveled so that a particular study may take place, enabling the researcher to see new horizons, just as we intend this text to be used.

\section{OBJECTIVES}

To report the experience of using hospital architectural designs for a historical-documentary research, aiming to share the experience with other researchers who also intend to use architectural designs of hospitals in documentary analysis studies.

\section{METHODS}

This is an experience report about the documentary analysis of architectural designs of a model hospital, part of the doctoral thesis entitled Evidence of Nursing power expressed in architectural designs of a reference model hospital in São Paulo: 1974-2002, whose temporal delimitation had 1974 as the initial milestone, the year of preparation of the first official publication of the Norms for the construction and installation of the General Hospital, and the final in 2002, with the latest version published of the Collegiate Board Resolution (Resolução de Diretoria Colegiada-RDC) No. 50/2002.

Respecting the ethical standards in research, this research's project was submitted to analysis by the Research Ethics Committee (CEP) of Universidade Federal de São Paulo (Unifesp), in compliance with the institution's regulation, according to Resolution 
MS 112 / 2012. The project was approved on October 16, 2015. The license agreement to use image (architectural designs) was approved and signed by the model reference hospital in focus, on December 7, 2016. The Free and Clarified Consent Term (TCLE) was not used, because this research makes use of documents.

The sources that could make this research feasible were listed after extensive discussions and studies. As a product of this process, we agreed that the historical documentation that represented the physical transformations occurred in EAS formalized by norms of federal scope that preceded RDC no 50/2012 and itself, besides the documents dealing with the physical transformations occurred in the reference model hospital studied, would be useful for the purpose of the research and, after this, the collection of documents began to be executed.

For this article, it is relevant to report how the collection, organization and treatment of the architectural designs of the reference model hospital took place. The handling of the architectural designs will be described below.

\section{Trajectory of the use of architectural designs in the nurs-} ing history research

The architectural designs of a reference model hospital elaborated during the period from 1974 to 2002, when transformations occurred in the norms for the construction and renovation of EAS, were selected to compose the list of documents that, methodologically treated, gave subsidies to answer the thesis of a historical research that was based on this methodological route.

In this perspective, it was important to contextualize the choice of the model hospital. Thus, the hospital selected for study had, in its history, the intersection with the transitional processes of the hospital architecture from pavilion to vertical. It is a century-old institution that went through the whole period of transformation of the norms for renovation and construction of EAS. The hospital also presents interesting and profound structural transformations, including service profile, assistance model, organizational structure, architecture, among others, justifying, therefore, that it is a reference model that will allow a view of the relations between the norm and its practical interpretation, that is, through this historical source it will be possible to produce the discussion in a real field and thus, how this interpretation really happened.

The centennial reference model hospital is located in the municipality of São Paulo and began its history in 1903, in a rented property on Brigadeiro Luiz Antônio street. On November 10, 1904, its sponsor purchased the state with a total area of $15,783 \mathrm{~m}^{2}$ and $75 \mathrm{~m}^{2}$, located at the start of Paulista Avenue and hired as the protagonist of the project the engineer Maximilian Hehl, also author of Catedral da Sé project. Changes and extensions happened in the history of this institution, that would come to have six interconnected buildings called blocks, which would be named by letters of the alphabet: $A$, B, C, D, E and F. Block C was constructed in 1934 , block B in 1949, block E in 1954, block D in 1963, block A in 1977 and block F in 2002. That year, the hospital had 350 beds, 11 operating rooms, nine beds for intensive care, five delivery rooms and a nursery for 100 beds $^{(3)}$.

Over the years, the reference model hospital had more buildings added, had its constructions adapted to each standard of construction and renovation of EAS, which was promulgated during the period studied, and kept all the collection of these transformations, that is, the architectural designs.

The set of rules on renovation and construction of EAS constituted the first step of data collection of the doctoral thesis mentioned in the text of the method. The trajectory for localization, survey, certification and legal approval for the use of the architectural designs lasted about two and a half years.

The search for the architectural drawings was made through telephone contact with the elected institution and visit to its historical museum, but the desired documents were not found at that time. On August 17, 2014, the documentation containing the research project and the letter explaining details of the study that would be carried out was sent to the institution for evaluation by its Ethics Committee. The process of requesting the documents was transferred to other instances and only in April 2015 a verbal authorization was granted for physical access to all the architectural drawings of the institution, namely digitized copies of floor plans, cuts, façades, implementation and details of architecture projects. On May 4, 2015, the electronic files related to the projects were assigned by the Engineering and Projects sector, which were, at the time, 1,407 drawings dated from 1906 to 2015.

In September 2016, when the projects that would be used in this research were finally selected and gathered, a signed license document was required for the use of images and, at the time, the institution refused to grant the legal license. Some months of negotiation were necessary, and then, on December 7, 2016, the license agreement to use images was finally signed. From that moment on, the research continued, but another great challenge arose, the organization of these documents.

In the first step, the drawings were spread in worksheets, organized by location, block, description, leaf number, date and pipe (where the physical project was kept). Thus, the designs of interest for the thesis were selected, using the selecting process of the software Microsoft Excel, creating a new arrangement of data, with a serial number for each document. For this purpose, only documents dated from 1974 to 2002 were selected, referring to architecture designs of wings and hospital units where care was provided by health professionals to patients who attended this service. Likewise, all administrative wing projects in which health professionals performed coordination activities of health services were considered. Thus, what guided this criterion of inclusion of the sectors with health professionals and exclusion from other facilities was precisely because it involved areas in which health professionals circulated exercising their functions, interacting among themselves and with clients/patients.

In the second step, 14 architectural designs remained, which were used as a historical source for the preparation of a doctoral thesis.

The worksheet was developed containing significant data for the study of the architectural designs, for example, the variables: location of the architectural design in the physical plant of the institution, the description of the type of design, the year of creation of the architectural design and the link to the drawing, which is in the file format ".jpeg". Since it is an Excel program, it is possible to select the drawings and information using any of the variables above mentioned. The worksheet contains 18 kilobytes.

Based on this organization of the data, the third step involved the comprehensive reading of these documents with the elaboration of 
analytical records containing: data related to the context in which the document was produced, which means, the social, political and economic universe of the author and of those, to whom it was destined, at the time when the document was produced; authorship, that is, the interests (confessed or not) of the document, its reasons and of those to whom they are addressed; the authenticity and reliability of the document, that is, to ensure the quality of the information transmitted through the data contained in the stamp, which is the space destined to identify the company and the person in charge of the project, customer and project identification, title of the drawing, scales, date, among others; the nature of the text and, finally, the preliminary analysis of the document, involving data referring to: denomination of space, measurements, compartment position, flows (accesses and location), sanitation conditions, facilities and private compartments. The analytical chart, prepared according to the sequence and format previously described, can be seen in Figure 1.

The careful reading of each document, that is, of each architectural design, was facilitated by analyzing the drawings in "areas of analysis", called: architectural design, details of the compartments and stamp, as can be seen in Figure 2. Thus, gradually, the relevant data of each project were extracted and systematically organized to compose the results of the thesis that originated this methodological route.

As the worksheets were created, they were also grouped by relevance and similarity, in the fourth step, resulting in the

\section{Analytical chart of architectural designs of the reference model hospital}

Serial number_-
Date_-
1. Context

$\overline{ }$

2. Authorship

3. Authenticity and reliability

4. Nature of the document

5. Key concepts and internal logic of the document

6. Preliminary analysis

Source: Based on Cellard ${ }^{(11)}$.

Figure 1 - Analytical chart of architectural designs of the reference model hospital construction of categories of analysis for the presentation of the results. The findings will then be described and interpreted in the light of the scientific literature found on the subject.

At the end of the work with this source, each catalographic record was connected to the respective architectural design, identified by a specific coding, as already explained, allowing the data set to be stored in a properly identified electronic file, being consolidated as the personal collection of the main researcher, with the purpose to be employed in future studies.

\section{CONCLUSIONS}

A historical-documentary research is a precious resource for the interpretation of a particular historical context, but requires skill and care in handling the historical source. The document should be carefully selected, organized and analyzed, so that the research achieves success.

In this study, legally assigned architectural designs were used by means of a license to use the image by a reference model hospital, which met the criteria to participate in the study.

This license document for image use included the session of the architectural designs of that institution, dated from 1974 to 2002 , to be used in research studies.

The documents collected were organized on a spreadsheet and the projects were digitalized and organized in alphanumeric order, allowing the selection of documents of interest for this study, complying with the criteria of the current research regarding the temporal delimitation and spaces of interest. The analytical phase of historical sources was facilitated by the development of an instrument that subsidized the construction of categories of results.

As limitations, this study could not to cover all the possibilities of using architectural designs in historical studies in the nursing 
area. Nevertheless, it is an experience that can be replicated and receive contributions or give support to other researchers who work or intend to work with similar sources, so this is its contribution to the area.

\section{FUNDING}

Brazilian Federal Agency for Support and Evaluation of Graduate Education (Capes).

\section{REFERENCES}

1. Le Goff J. História e memória. Campinas: Editora da Unicamp; 2016.

2. Flick U. A redação e o futuro da pesquisa qualitativa: arte ou método? In: Introdução à pesquisa qualitativa. $3 \neg a$ ed. Porto Alegre: Artmed; 2009.

3. Pastro C. Hospital Santa Catarina: 1906-2006. São Paulo: Grafa; 2006.

4. Silva JMC. Um acervo, uma coleção e três problemas: a Coleção Jacques Pilon da Biblioteca da FAUUSP. An Mus Paul. 2016;24(3):45-70. doi: 10.1590/1982-02672016v24n0302

5. Nightingale F. Notes on hospitals. 3rd ed. London: Savill \& Edwards; 2010.

6. Miquelin LC. Anatomia dos edifícios hospitalares. São Paulo: CEDAS; 1992.

7. Draganov PB, Sanna MC. Architectural drawings from hospitals described in Florence Nightingale's "Notes on hospitals" book. Hist Enferm Rev Eletrônica [Internet]. 2017 [cited 2018 Jun 10];8(2):94-105. Available from: http://here.abennacional.org.br/here/v8/n2/a04.pdf

8. Foucault M. Microfísica do poder. 17a ed. Rio de Janeiro: Graal; 2012.

9. Sanna MC. The structure of knowledge in Nursing Administration. Rev Bras Enferm. 2007;60(3):336-8. doi: 10.1590/S0034-71672007000300017

10. Draganov PB, Vieira RQ, Sanna MC. Recursos físicos em ambientes hospitalares no Brasil: um estudo bibliométrico. Rev Bras Bibliotecon Documen [Internet]. 2016 [cited 2018 July 11];12(1):89-109. Available from: https://rbbd.febab.org.br/rbbd/article/view/424/489

11. Cellard A. A análise documental. In: Poupart J, Deslauriers JP, Groulx LH, Laperrière A, Mayer R, Pires A, organizadores. A pesquisa qualitativa: enfoques epistemológicos e metodológicos. Petrópolis: Vozes; 2008. p. 295-316. 